\title{
Penyelenggaraan dan Tantangan Ekonomi Berbasis Syariah
}

\author{
Authors: \\ Zakirah Zakirah ${ }^{1}$, Try Saadurrahman HM Kafrawi ${ }^{2}$, Agus Basri $^{3}$, Muhammad Fadhil $^{4}$
}

\author{
${ }^{1}$ Institut Agama Islam Negeri (IAIN) Sultan Amai Gorontalo , Indonesia \\ Email: zakirahira17@gmail.com \\ ${ }^{2}$ Sekolah Tinggi Agama Islam (STAI) Darul Dakwah Wal-Irsyad (DDI) Kota Makassar, Indonesia \\ Email: saadbarkah37@gmail.com \\ ${ }^{3}$ Sekolah Tinggi Agama Islam (STAI) Darul Dakwah Wal-Irsyad (DDI) Kota Makassar, Indonesia \\ Email: agusbasritakko@gmail.com \\ ${ }^{4}$ Sekolah Tinggi Agama Islam (STAI) Darul Dakwah Wal-Irsyad (DDI) Kota Makassar, Indonesia \\ Email: muhammadfadhilyns@gmail.com
}

\begin{abstract}
Abstrak:
Dari sisi teologis, sejatinya seorang muslim yakin bahwa al-Qur'an dan hadis telah mengatur jalan kehidupan ekonominya. Untuk mewujudkan kehidupan ekonomi tersebut, Allah swt telah menyediakan sumber daya-Nya dan mempersilahkan manusia untuk memanfaatkannya. Kenyataannya, sistem ekonomi dunia dikuasai oleh sistem ekonomi konvensional yang jauh lebih kuat perkembangannya daripada sistem ekonomi Islam. Dengan demikian, menghadirkan penyelenggaraan ekonomi berbasis syariat tersebut juga tidak cukup hanya melalui dakwah dan sosialisasi secara terus menerus.
\end{abstract}

Kata Kunci: Penyelenggaraan,Tantangan, Ekonomi, Berbasis Syariah

\section{PENDAHULUAN}

Dimensi sosial merupakan satu dari lima aspek yang melekat pada agama, di samping dimensi lain seperti ritual, mistikal, ideologikal, dan intelektual. Dimensi sosial adalah manifestasi ajaran agama dalam kehidupan bermasyarakat, ${ }^{1}$ dalam arti perilaku manusia pada semua tahap dan aspeknya menjadi cakupan agama. Pemahaman tersebut dapat dipetik dari definisi agama itu sendiri. Agama -paling tidak- didefinisikan sebagai seperangkat kepercayaan dan aturan yang pasti untuk membimbing manusia dalam tindakannya, baik terhadap Tuhan (habl min Allāh) atau antar manusia (habl min al-nās). ${ }^{2}$ Untuk konteks hubungan antar manusia, sisi kehadiran agama dapat dilihat dalam pengaturan masalah ekonomi.

${ }^{1}$ Jalaluddin Rakhmat, Islam alternatif: Ceramah-Ceramah di Kampus (Bandung: Mizan, 2004), h. 37-38.

${ }^{2}$ Ali Anwar Yusuf, Islam dan Sains Modern: Sentuhan Islam terhadap Berbagai Disiplin Ilmu (Bandung: Pustaka Setia, 2006), h. 143. 
Terma ekonomi pada umumnya didefinisikan sebagai kajian tentang perilaku manusia, dalam hubungannya dengan pemanfaatan sumber-sumber produktif yang langka untuk memproduksi barang dan jasa, serta mendistribusikannya untuk dikonsumsi sebagai pemenuhan berbagai kebutuhan hidup. ${ }^{3}$ Jika kemudian ekonomi menjadi salah satu aspek yang dicakup dalam pembicaraan agama (Islam), maka tentu menjadi sangat jelas bahwa syariat pasti telah memberi tuntunan menyangkut kehidupan ekonomi manusia. Indikator tatanan ekonomi Islam tersebut setidaknya dapat dipahami dari petunjuk al-Qur'an surat al-Mutaffifin ayat $1-3^{4}$ yang menunjukkan bahwa perilaku curang dalam aktifitas ekonomi menjadi suatu perbuatan terlarang. Walhasil, aktifitas ekonomi dalam Islam sesungguhnya merupakan salah satu manifestasi tanggung jawab manusia sebagai khalifah fi al-ard. Hal ini menunjukkan betapa besar kekuasaan Allah dan betapa kecilnya kekuatan kita. Ini jelas memotivasi kita untuk lebih membangun ketergantungan dan rasa tawakkal kita kepada Allah jalla wa 'ala'.

Perlu ada upaya-upaya realistis dan strategis yang dilakukan agar cita-cita penyelenggaraan ekonomi syariah dapat direalisasi secara maksimal, khususnya dalam konteks membumikan ekonomi syariah di Indonesia yang masyarakatnya memang mayoritas menganut agama Islam.

${ }^{3}$ Endang Saefuddin Anshari, Kuliah al-Islam; Pendidikan Agama Islam di Perguruan Tinggi (Jakarta: Raja Grafindo Persada, 1992), h. 154.

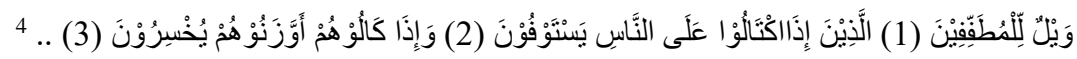

Terjemahnya: "Celakalah bagi orang-orang yang curang (dalam menakar dan menimbang). (Yaitu) orang-orang yang apabila menerima takaran dari orang lain mereka minta dicukupkan, dan apabila mereka menakar atau menimbang (untuk orang lain), mereka mengurangi......" . Departemen Agama RI., Al-Qur'an dan Terjemahnya (Jakarta: Yayasan Penterjemah al-Qur'an, 1983), h. 587.

${ }^{5}$ Sapada, A. O. (2020). Mendidik Anak Menjadi Anak Sholeh,. h. 3. 


\section{PEMBAHASAN}

\section{A. Filosofi Ekonomi dalam Syariah Islam}

Prinsip ekonomi Islam sesungguhnya telah dipraktikkan sejak masa Nabi Muhammad saw dan terus merambat ke masa Dinasti Umayyah dan Abbasiyah. Pada masa Nabi, model-model transaksi seperti menghimpun dana umat, pinjam-meminjam uang dan barang, penyaluran dana kepada masyarakat, ditangani oleh lembaga keuangan yang dipimpin oleh Zubair bin Awwam dan lembaga keuangan lainnya yang dipimpin oleh Ibnu Abbas. Pada masa Abbasiyah, prinsip perbankan tampak ke permukaan, yaitu pada masa pemerintahan al-Muqtadir (908-932). ${ }^{6}$

Secara ringkas dapat dikatakan bahwa, tujuan ekonomi Islam adalah makmur dan sejahtera, adil dan merata, tentram (stabil) dan maju, serasi dan damai, merdeka, kelestarian alam, dan mandiri. Muara akhir dan tujuan ideal ekonomi Islam adalah melepaskan tali belenggu kemiskinan yang selama ini melilit mayoritas umat Islam, agar porsi mereka tidak hanya dijadikan sebagai objek pasaran dan konsumen belaka.

Selain itu pula dapat dikemukakan pengertian ilmu ekonomi islam adalah pengetahuan dan aplikasi dari anjuran dan aturan Syariah ah yang mencegah ketidak adilan dalam memperoleh sumber-sumber daya materiel sehingga tercipta kepuasan manusia dan dan memungkinkan mereka menjalankan perintah Allah dan mengikuti aturan masyarakat. ${ }^{7}$

Dengan kata lain, tujuan ekonomi Islam adalah menciptakan kehidupan manusia yang aman dan sejahtera, terpenuhinya segala kebutuhan baik lahir maupun batin, demi mencapai kebaikan dan kebahagiaan di dunia dan kebaikan di akhirat. ${ }^{8}$

Ada beberapa nilai filosofis yang secara spesifik menjadi karakteristik ekonomi syariah, ${ }^{9}$ yaitu:

${ }^{6}$ Atang Abd. Hakim, Fiqih Perbankan Syariah; Transformasi Fiqh Muamalah ke dalam Peraturan Perundang-Undangan (Bandung: Refika Aditama, 2011), h. 41.

${ }^{7}$ Akbar, A., Dahri, M., \& Arsyam, M. (2021). Konsep Dasar Ekonomi Dan Transaksi Dalam Muamalah Islam,. h. 3. Ilmu, h. 231.

${ }^{8}$ Ali Anwar Yusuf, Islam dan Sains Modern: Sentuhan Islam terhadap Berbagai Disiplin

${ }^{9}$ Syarifah Gustiawati Mukri, Langkah Strategis Optimalisasi Sistem Ekonomi Syariah. https://journal.uinjkt.ac.id/index.php/salam/artcle/downloadSuppFile/1521/97.x (Diakses 20 Juni 2018). 
1. Nilai keTuhanan. Menurut Yusuf al-Qardhawi, ekonomi syariah adalah ekonomi yang bercirikan keTuhanan. Sistem ini bertitik tolak dari Allah, bertujuan akhir kepada Allah. Penggunaan sarana dan fasilitas dari Allah ini dilakukan melalui hukum dan syari'at Allah swt. Ketika seorang muslim menggunakan atau menikmati sesuatu di dunia ini, secara langsung ia telah melakukan ibadah kepada Allah, dan merupakan sebuah kewajiban baginya untuk mensyukuri segala nikmatNya yang telah diberikan kepadanya. Berdasarkan nilai filosofis ini, dalam ekonomi syariah muncul sebuah norma yang disebut norma al-istikhläf. Adanya norma istikhlāfini makin mengukuhkan norma keTuhanan dalam ekonomi syariah. Sebab, seorang muslim wajib percaya bahwa ia makhluk Allah, ia bekerja di bumi Allah, dengan kekuatan dari Allah, dan melalui sarana dan prasarana dari Allah. Seorang muslim bekerja sesuai dengan hukum kausalitas. Jika ia memperoleh harta, maka pada hakikatnya itu adalah harta Allah yang dititipkan kepadanya. Allahlah yang menciptakan harta itu, dan Dia-lah pemilik sejati. Sementara itu, manusia hanya sebagai penjaga amanah yang telah diberikan kepadanya. ${ }^{10}$

2. Nilai Dasar Kepemilikan (al-Milkiyah). Konsep kepemilikan dalam Islam tidak sama dengan konsep kepemilikan dalam faham liberalisme seperti yang dikemukakan oleh Jhon Locke. Menurut Jhon Locke, setiap manusia adalah tuan serta penguasa penuh atas kepribadiannya, atas tubuhnya, dan atas tenaga kerja yang berasal dari tubuhnya. Artinya, kepemilikan yang ada pada diri seseorang adalah bersifat absolut. Oleh karena itu untuk apa dan bagaimana dia menggunakan harta tersebut adalah mutlak tergantung kepada kehendak dirinya. Hal ini tidak disetujui oleh Karl Marx. Marx berpendapat bahwa hal yang seperti itu adalah sangat berbahaya karena akan membawa kepada kehidupan yang eksploitatif dan penuh konflik. Berbeda dengan dua pandangan tersebut di atas, Islam mengakui kepemilikan individual. Di samping itu, Islam pun mengakui akan adanya kepemilikan oleh masyarakat dan oleh negara. Akan tetapi, kepemilikan tersebut tidak bersifat absolut, tetapi bersifat relatif. Artinya, bahwa kepemilikan yang ada

\footnotetext{
${ }^{10}$ Lihat Yusuf Qardhawi, Norma dan Etika Ekonomi Islam (Jakarta: Gema Insani Press, 1997),
} h. 31-32. 
pada seseorang atau masyarakat atau negara tersebut bukanlah sepenuhnya milik dan hasil dari usaha mereka. Akan tetapi, semua itu merupakan amanat dan titipan dari Allah swt. Oleh karena itu, seseorang tidak boleh menghambur-hamburkan hartanya, atau bahkan menuhankan hartanya. Jika demikian, berarti harta tersebut akan kehilangan fungsi sosial dan nilai manfaatnya. ${ }^{11}$ Sehingga dalam ajaran Islam, kepemilikan manusia bukanlah penguasaan mutlak atas sumber-sumber ekonomi, karena pemilik mutlaknya adalah Allah, manusia hanya diberi amanat dan kemampuan untuk memanfaatkan sumber-sumber yang diamanatkan tersebut. Di samping itu, meskipun Tuhan telah memberikan kebebasan kepada manusia untuk mendapatkan manfaat, namun tidak semua manfaat dapat dikuasai dan dimiliki individu. Sumber-sumber daya alam yang menyangkut kepentingan umum atau yang menjadi hajat hidup orang banyak, harus menjadi milik umum atau milik negara.

3. Keseimbangan (al-Muwāzanah). Sistem ekonomi kapitalis lebih mementingkan individu dibanding dengan masyarakat. Pada sistem ini seseorang merasakan harga diri dan eksistensinya. Orang diberi kesempatan untuk mengembangkan segala potensi dan kepribadiannya. Namun, akhirnya seseorang terkena penyakit egoistis, materialistis, pragmatis, dan rakus untuk memiliki segala sesuatu, dan orientasi kehidupannya merupakan profit motif. Dalam ajaran Islam, masalah keseimbangan mendapat penekanan dan perhatian secara khusus. Tidak hanya adanya keseimbangan antara kepentingan seseorang dengan kepentingan bersama, antara kepentingan dunia dan akhirat, antara kepentingan jasmani dan rohani, antara idealisme dan realita. Akan tetapi juga, keseimbangan antara modal dan aktifitas, antara produksi dan konsumsi, serta adanya sirkulasi kekayaan. ${ }^{12}$ Oleh karena itu, Islam mencegah dan melarang terjadinya akumulasi dan konsentrasi kekayaan

\footnotetext{
${ }^{11}$ Lihat, Anwar Abbas , Dasar-Dasar Ekonomi Islam. Dalam, Syarifah Gustiawati Mukri, Langkah Strategis Optimalisasi Sistem Ekonomi Syariah. https://journal.uinjkt.ac.id/index.php/ salam/artcle/downloadSuppFile/1521/97.x (Diakses 20 Juni 2018). 1995), h. 84

${ }^{12}$ Yusuf Qaradhawi, Peran dan Nilai Moral dalam Perekonomian (Jakarta: Rabbani Press,
} 
hanya pada segelintir orang. ${ }^{13}$ Sebaliknya jika terjadi kesenjangan kepemilikan yang tajam antar individu, berkaitan dengan pemenuhan kebutuhan-kebutuhannya, berarti telah terjadi praktek kezaliman. Untuk mengantisipasinya, Islam telah menawarkan solusi pemecahan melalui instrumen zakat, infaq dan sadaqah yang dapat menyentuh dan sekaligus mengentaskan kemiskinan. Keseimbangan merupakan nilai dasar yang mempengaruhi berbagai aspek tingkah laku seorang muslim. Nilai dasar keseimbangan ini harus dijaga sebaik-baiknya, bukan saja antara kepentingan dunia dengan kepentingan akhirat dalam ekonomi, tetapi juga keseimbangan antara hak dan kewajiban antara kepentingan individu, masyarakat serta dapat diketahui pula bahwa seorang pedagang wajib berlaku jujur dalam melakukan usaha jual beli. Jujur dalam arti luas. Tidak berbohong, tidak menipu, tidak mcngada-ngada fakta, tidak bekhianat, serta tidak pernah ingkar janji dan lain sebagainya. $^{14}$

4. Nilai Dasar Persaudaraan dan Kebersamaan (al-Ukhuwwah wa al-Isytirākiyyah wa al-Jamā'ah). Pada paham sosialisme dan komunisme, persaudaraan dan kebersamaan merupakan nilai yang utama dan pertama. Untuk itu, agar nilai-nilai tersebut tidak rusak dan tidak terganggu maka kepemilikan individual yang menjadi penyebab terjadinya perselisihan dan persengketaan harus dihapuskan dan digantikan oleh negara. Negaralah yang mengatur produksi, konsumsi dan distribusi masyarakat. Dalam paham kapitalisme, hal ini tidaklah terlalu menjadi perhatian. Bagi mereka persaudaraan akan dapat terjadi secara otomatis diluar maksud para pelaku ekonomi itu sendiri, karena perekat persaudaraan, menurut paham ini adalah kepentingan. Kedua paham di atas, berbeda dengan ajaran Islam. Dalam Islam, kebersamaan merupakan indikator atas keimanan seorang muslim. Nilai-nilai persaudaraan merupakan konsekuensi logis dari penunjukan manusia sebagai khalifah fî al-ard, karena penunjukan tersebut bukan hanya ditujukan

\footnotetext{
${ }^{13}$ Lihat QS. al-Hasyr/59: 7; “... supaya harta itu jangan hanya beredar di antara orang-orang yang kaya saja di antara kamu...".

${ }^{14}$ Usman, H. A., Arsyam, M., \& Yusuf, M. (2021). ETIKA PERDAGANGAN DALAM ISLAM,. h. 1.
} 
kepada orang-orang tertentu saja. Akan tetapi, ditujukan kepada setiap hamba-Nya yang beriman. Oleh sebab itu, perbedaan ras, etnik, dan bahasa bukanlah menjadi variabel pembeda di mata Allah swt. ${ }^{15}$

5. Nilai Dasar Kebebasan (al-Istiqlāliyyah). Dalam sistem ekonomi kapitalisme, setiap individu diberikan kebebasan yang seluas-luasnya untuk memanfaatkan atau tidak memanfaatkan harta yang dimilikinya. Juga untuk masuk atau tidak masuk ke dalam pasar, baik sebagai produsen, distributor, atau konsumen. Atau dengan perkataan lain, tidak ada yang bisa mengatasi kebebasan seseorang individu kecuali dirinya sendiri. Hal ini tidak dapat diterima oleh paham sosialis-komunis. Mereka melihat bahwa kebebasan seperti itu akan membawa kepada tindakan anarkis. Oleh sebab itu, kebebasan tersebut harus ditundukkan kepada kepentingan bersama. ${ }^{16}$ Dalam persepsi Islam, kebebasan manusia sangat dihormati. Namun, kebebasan tersebut dibingkai dan direstriksi oleh payung ahkām al-syar'iyyah yang membatasi kebebasan tersebut dengan norma-norma hukum. Jika hal itu dilanggar, maka kewajiban bagi negara untuk bertindak menyelesaikannya. ${ }^{17}$

6. Nilai Dasar Keadilan (al-'Adālah). Keadilan yaitu memberikan setiap hak kepada para pemiliknya masing-masing tanpa melebihkan dan mengurangi. ${ }^{18}$ Pada sistem sosialisme dan komunisme, yang menentukan keadilan itu merupakan otoritas negara, sedang dalam sistem kapitalisme yang berkompeten adalah otoritas individu. Sementara itu, menurut persepsi Islam yang menetapkan keadilan itu merupakan otoritas dan kewenangan dari Allah swt. Namun perlu dicatat bahwa dorongan tersebut bisa saja menjerumuskan manusia pada kebinasaan (kemudaratan) bila tidak diatur secara bijak mekanisme pelampiasannya dengan benar. ${ }^{19}$ Dalam

\footnotetext{
${ }^{15}$ Yusuf Qaradhawi, Peran dan Nilai Moral dalam Perekonomian, h. 84.

${ }^{16}$ Lihat, Anwar Abbas, Dasar-Dasar Ekonomi Islam. Dalam, Syarifah Gustiawati Mukri, Langkah Strategis Optimalisasi Sistem Ekonomi Syariah. https://journal.uinjkt.ac.id/index.php/ salam/artcle/downloadSuppFile/1521/97.x (Diakses 20 Juni 2018).

${ }^{17}$ Yusuf Qaradhawi, Peran dan Nilai Moral dalam Perekonomian, h. 390.

${ }^{18}$ Yusuf Qaradhawi, Peran dan Nilai Moral dalam Perekonomian, h. 390.

${ }^{19}$ Nursalam, N., Basri, A., \& Akbar, A. Implementasi Nikah Dalam Al-Qur'an (Studi Pendekatan Tafsir Maudu'i), h. 16.
} 
masyarakat sosialisme dan komunisme, yang menjadikan kebersamaan dan kesamarataan sebagai nilai utama, maka faktor kebutuhan dijadikan dasar untuk menentukan sesuatu itu adil atau tidak. Menurut paham ini, suatu masyarakat baru dikatakan adil jika semua kebutuhan warganya telah terpenuhi, terutama kebutuhan sandang, pangan dan papan. Sebaliknya, jika tidak, maka telah terjadi praktek kedzaliman. Sementara itu, menurut kapitalisme liberal, konsep keadilan tidaklah didasarkan kepada kebutuhan, namun bertumpu kepada kebebasan itu sendiri. Menurut paham ini, adilnya sesuatu haruslah dibagi menurut usaha-usaha bebas dari individu-individu yang bersangkutan, sedangkan yang berpangku tangan, tidak berusaha, maka tidak memperoleh hak untuk memperoleh sesuatu. Keadilan menurut paham ini lebih dikenal dengan term "keadilan distributif". Oleh karena itu, menurut teori keadilan liberalistis ini, membantu orang yang miskin atau dalam kesulitan sebagai sesuatu yang tidak etis, karena mereka dalam mendapatkan sesuatu tanpa mengeluarkan air keringat sendiri. Di pihak lain, Islam mempunyai konsep tentang keadilan ditinjau dari segi kesesuaian dan tidaknya dengan ruh ajaran Islam, sebagaimana yang telah digariskan di dalam al-Qur'an dan Hadis. Dengan demikian kita akan semakin yakin bahwa Al-Quran adalah petunjuk jalan kebenaran, tidak ada keraguan di dalamnya, kemuliaannya dan kesuciannya itu membawa berita gembira bagi orang membaaca dan meyakininya. ${ }^{20}$ Oleh sebab itu, sikap peduli terhadap orang fakir, miskin dan $d^{\prime} u^{\prime} a f^{-}$' serta tertindas sebagai sebuah praktek keadilan. Sebab, hal tersebut merupakan sikap mental, sebagai sebuah praktek keadilan yang diwajibkan atau dianjurkan oleh agama. Sebaliknya, dengan mengabaikannya dianggap sebagai sebuah praktek kezaliman. ${ }^{21}$

\footnotetext{
${ }^{20}$ Akbar, A., Basri, A., \& Jamaluddin, H. (2021). Konsep Integrasi Ilmu Agama Dan Ilmu Umum,. h. 9

${ }^{21}$ Syarifah Gustiawati Mukri, Langkah Strategis Optimalisasi Sistem Ekonomi Syariah. https://journal.uinjkt.ac.id/index.php/ salam/artcle/downloadSuppFile/1521/97.x (Diakses 20 Juni 2018).
} 


\section{B. Alas Sejarah Ekonomi Syariah ${ }^{22}$ di Indonesia}

Sepanjang sejarah ekonomi Islam, kebebasan ekonomi sudah dijamin dengan berbagai tradisi masyarakat dan dengan sistem hukumnya. Nabi saw tidak bersedia menetapkan harga-harga walaupun pada saat harga-harga itu melambung tinggi. Setelah masa Nabi saw dan selama sejarah perjalanan Islam, umat muslim mempertahankan prinsip kebebasan yang senantiasa dilakukan. Setelah perang dunia kedua, muncul gejala yang menarik di negara-negara Islam atau negara yang penduduknya mayoritas muslim, yaitu adanya kecenderungan untuk melihat potensi diri dengan menengok nilai-nilai Islam agar dapat digunakan dalam mengatur hidup dan kehidupan umat Islam dalam bermasyarakat dan bernegara, termasuk kebijakan ekonominya.

Babak baru kemajuan ekonomi Islam dalam tiga dasawarsa sebagai bagian dari ilmu-ilmu keislaman, dimulai dari kajian-kajian ilmiah tentang ekonomi dan keuangan Islam di Timur Tengah serta negara-negara muslim lainnya sejak pertengahan dekade 1970-an. Buah dari kajian-kajian itu adalah didirikannya Islamic Development Bank di Jeddah pada tahun 1975 yang kemudian diikuti oleh pendirian bank-bank Islam lainnya ${ }^{23}$ di belahan dunia. Pada saat yang sama, bertumbuhkembangnya bank-bank yang berbasis syariah di beberapa negara Islam menjadi motivasi bagi forum-forum ulama di Indonesia untuk mendirikan bank syariah.

Di Indonesia, pendirian bank syariah berhubungan dengan sistem sosial dan entitas kehidupan masyarakat seperti ekonomi, politik, budaya, dan keyakinan keagamaan. ${ }^{24}$ Sebelum muncul gagasan tentang perlunya didirikan bank Islam di

\footnotetext{
${ }^{22}$ M. Cholil Nafis menyatakan bahwa penggunaan term "syariah" -khususnya dalam konteks pembicaraan ekonomi Islam- adalah khas Indonesia. Di negara lain, kata "Islam" yang digunakan. Karena itu, di Indonesia digunakan istilah-istilah seperti "Bank Syariah", bukan "Bank Islam". Lihat, M. Cholil Nafis, Teori Hukum Ekonomi Syariah (Jakarta: UI-Press, 2011), h. iii. Pandangan yang kurang lebih sama dengan M. Cholil Nafis juga dikemukakan oleh Atang Abdul Hakim dalam, Atang Abdul Hakim, Fiqih Perbankan Syariah; Transformasi Fiqih Muamalah ke Dalam Peraturan PerundangUndangan, h. 40.

${ }^{23}$ Imron Abdullah, "Islam Ditinjau dari Aspek Ekonomi”, Kata Pengantar dalam Abdul Aziz dan Mariyah Ulfah, Kapita Selekta Ekonomi Islam Kontemporer (Bandung: Alfabeta, 2010), h. vi.

${ }^{24}$ Atang Abdul Hakim, Fiqih Perbankan Syariah; Transformasi Fiqih Muamalah ke Dalam Peraturan Perundang-Undangan, h. 39.
} 
Indonesia, para pakar/cendekiawan muslim baik yang ada di organisasi keagamaan maupun kalangan perbankan dan perorangan telah melakukan pengkajian tentang bunga bank dan riba. KH. Mas Mansur, ketua pengurus Muhammadiyah pada tahun 1937 telah mempunyai keinginan untuk berdirinya bank Islam. Keinginan tersebut gagal karena ia dianggap SARA pada saat itu dan dikahawatirkan akan mengganggu stabilitas nasional. Majelis Tarjih Muhammadiyah pada Muktamar di Sidoarjo tahun 1968 memutuskan bahwa bunga bank hukumnya termasuk syubhat. Karena itu menurut mereka, untuk menjaga prinsip ihtiyät perlu ada rambu-rambu untuk menentukan besar kecilnya bunga atau keuntungannya siapa yang peroleh dan untuk siapa keuntungan itu dimanfaatkan. Sementara itu, baḥs al-masāil NU memfatwakan bahwa bunga bank itu halal, karena bunga bank itu pada hakikatnya merupakan pemanfaatan uang. ${ }^{25}$

Gagasan pendirian bank syariah di Indonesia dibicarakan pada seminar nasional tentang "Hubungan Indonesia-Timur Tegah" (1974) dan seminar internasional yang diselenggarakan oleh Lembaga Studi Ilmu-ilmu Kemasyarakatan (LSIK) dan Yayasan Bhinneka Tunggal Ika (1976). Akan tetapi, ide itu belum bisa terwujud karena beberapa persoalan, seperti masalah payung hukum, politik dan juga permodalan.

Dalam kurun waktu antara 1988 hingga 1992, barulah bermunculan permohonan izin pendirian bank Islam. ${ }^{26}$ Dan titik awal pendirian perbankan yang mempergunakan prinsip syariah, secara faktual ditandai dengan berdirinya PT. Bank Muamalat Indonesia (BMI) TBK pada tahun 1991, dan memulai kegiatan

\footnotetext{
${ }^{25}$ Lihat, Warkum Sumitro, Asas-Asas Perbankan Islam dan Lembaga-Lembaga Terkait; Bamui, Takaful dan Pasar Modal Syariah di Indonesia (Jakarta: Raja Grafindo Persada, 2004), h. 81-82.

${ }^{26}$ Permohonan tersebut salah satunya diajukan oleh Ibu Saodah dari Lombok untuk mendirikan BPR Islam al-Azhar. Lalu ada BPRS Berkah Amal Sejahtera, BPRS Dana Mardhatillah, BPRS Amanah Rabaniah yang masing-masing beroperasi di Bandung, dan BPRS Hareukat yang beroperasi di Aceh. Semua BPR ini memperoleh izin usaha dari Bank Indonesia. Lihat, Karnaen A. Prawiraatmajdja dan Henri Tanjung, Bank Syariah; Teori, Praktik, dan Peranannya (Jakarta: Celestial Publishing, 2007), h. 88. BPR tersebut menyusul setelah pendirian Bank Muamalat Indonesia. Dan oleh karena lembagalembaga itu dirasakan kurang mencukupi dan belum menjangkau masyarakat bawah, maka didirikanlah lembaga simpan pinjam yang kemudian dikenal dengan istilah "Bait al-Ma>l wa al-Tamwi $>l$ " (BMT) atau "Bai >t al-Qira $>d\}$ " menurut masyarakat Aceh. Lihat misalnya, Abdul Aziz dan Mariyah Ulfah, Kapita Selekta Ekonomi Islam Kontemporer, h. 170.
} 
operasionalnya pada bulan Mei 1992. Pendirian bank dimaksud, diprakarsai oleh Majelis Ulama Indonesia (MUI), Pemerintah Indonesia, serta mendapat dukungan nyata dari eksponen Ikatan Cendekiawan Muslim Indonesia (ICMI) dan beberapa pengusaha muslim. Selain itu, pendirian Bank Muamalat Indonesia juga mendapat dukungan dari warga masyarakat yang dibuktikan dengan komitmen pembelian saham Perseroan senilai Rp. 84 miliar pada saat penandatanganan Akta Pendirian Perseroan, dan mendapat tambahan modal senilai 106 miliar dari masyarakat Jawa Barat dalam acara silaturrahmi peringatan pendirian bank tersebut di Istana Bogor. ${ }^{27}$

Ketika Bank Muamalat Indonesia berdiri yang kemudian diikuti oleh lembaga-lembaga keuangan lainnya, pada waktu itu sosialisasi ekonomi syariah dilakukan masing-masing lembaga keuangan syariah. Selain itu, momen penting yang tercatat dalam perkembangan ekonomi syariah di Indonesia adalah dari pengalaman selama krisis ekonomi yang terjadi dalam rentang waktu 1997 sampai 1998-an, ternyata fakta menunjukkan bahwa perbankan syariah tidak terseret badai krisis dan menjadi salah satu sektor perbankan yang tidak perlu dilakukan rekap oleh pemerintah. ${ }^{28}$

Walhasil, booming-nya usaha perbankan yang berbasis syariah di Indonesia, juga merupakan bentuk koreksi atas bank konvensional yang beroperasi dengan sistem bunga yang dianggap oleh sebahagian ulama sebagai riba. ${ }^{29}$ Terlebih masyarakat Indonesia yang memang mayoritas menganut agama Islam, tentu saja berkeinginan untuk menjalankan roda ekonominya pada prinsip-prinsip yang Islami. Karena itu, penguatan kelembagaan yang telah dilakukan melalui legislasi perbankan syariah, diharapkan mampu memberi jaminan kepastian hukum bagi stakeholders dan keyakinan kepada masyarakat dalam menggunakan produk dan jasa bank syariah.

\footnotetext{
${ }^{27}$ Lihat, Evita Isretno, Pembiayaan Mudharabah dalam Sistem Perbankan Syariah (Jakarta: Cintya Press, 2011), h. 1.

${ }^{28}$ Amran Suadi dan Mardi Candra, Politik Hukum: Perspektif Hukum Perdata dan Pidana Islam serta Ekonomi Syariah (Jakarta: Kencana, 2016), h. 422-423.

${ }^{29}$ Lihat, Abdullah Jayadi, Beberapa Aspek Penting tentang Perbankan Syariah (Cet. I; Yogyakarta: Mitra Pustaka, 2011), h. 1.
} 


\section{Tantangan Penyelenggaraan Ekonomi Syariah di Indonesia}

Secara komprehensif, perkembangan dan peluang ekonomi syariah di Indonesia belum menggembirakan karena ekonomi syariah masih menghadapi berbagai hambatan dan tantangan yang disebabkan oleh hal-hal sebagai berikut:

1. Belum maksimalnya sosialisasi ekonomi syariah, padahal berdasarkan hasil survei BNI Syariah sejak tahun 2005 menunjukkan bahwa penetrasi aset perbankan syariah pada 2004 baru sebesar 1,15 persen, sementara itu sekitar 51 persen masyarakat Indonesia menyatakan tidak setuju dengan bunga. Dengan demikian, secara optimis disimpulkan potensi pasar perbankan syariah dan lembaga keuangan syariah masih sangat besar. Karena itu, sosialisasi kepada masyarakat dengan para alim ulama, lembaga pendidikan, dan perbankan syariah merupakan suatu keniscayaan. Peran para ulama, tokoh masyarakat, dan lembaga perguruan tinggi Islam sangat strategis dalam menggalakkan sosialisasi ini, di samping sebagai praktisi lembaga keuangan syariah.

2. Masih lemahnya jaringan atau sinergi yang kuat antara sesama lembaga keuangan syariah dengan lembaga-lembaga sosial yang bergerak di bidang ekonomi umat, seperti dengan lembaga zakat dan wakaf.

3. Belum maksimalnya praktik atau penerapan ekonomi syariah. Secara teori ilmu ekonomi syariah telah dikembangkan melalui dunia pendidikan dan pengetahuan, baik di kampus-kampus, penelitian-penelitian ilmiah, kelompok-kelompok kajian, ataupun media massa. Bahkan saat ini ilmu ekonomi syariah telah berkembang tidak hanya di dunia pendidikan Islam, namun telah memasuki dunia pendidikan secara umum. Kampus-kampus besar di Indonesia telah melakukan kajian-kajian akademis terhadap fenomena dan perkembangan keilmuan ekonomi syariah. ${ }^{30}$

\footnotetext{
${ }^{30}$ Amran Suadi dan Mardi Candra, Politik Hukum: Perspektif Hukum Perdata dan Pidana Islam serta Ekonomi Syariah, h. 461-462.
} 
Selain yang dikemukakan di atas, beberapa masalah dan tantangan yang dihadapi ekonomi syariah dalam menyongsong prospek penyelenggaraan ekonomi syariah di Indonesia ke depan adalah:

1. Faktor kelembagaan. Dalam hal ini dipengaruhi setidaknya oleh dua unsur, yaitu: Pertama, permodalan yang masih terbatas dalam menghadapai periode pertumbuhan. Kedua, jaringan kantor belum luas dan masih belum memadai sehingga dirasakan layanan perbankan syariah sulit untuk ditemukan.

2. Faktor sumber daya manusia (SDM). Tantangan dalam hal ini yaitu masih belum memadainya SDM di bidang perbankan syariah, baik secara kuantitas maupun kualitas yang meliputi SDM pelaksana operasional bank syariah, SDM pengawas bank syariah di BI, dan SDM pada sektor penunjang seperti sektor keuangan lainnya, pendidikan, pengamat, dan sebagainya. Hal itu karena sistemnya belum lama dikembangkan.

3. Tingkat pemahaman masyarakat. Tingkat pemahaman masyarakat terhadap karakteristik operasi perbankan syariah yang masih sangat terbatas sehingga keinginan masyarakat yang tertarik terhadap perbankan syariah masih sebatas tingkat awareness. Adanya perbedaan karakteristik produk bank konvensional dengan bank syariah juga telah menimbulkan adanya keengganan bagi pengguna jasa perbankan. Hal itu timbul karena hilangnya kesempatan mendapatkan penghasilan tetap berupa bunga bank. Oleh karena itu secara umum perlu diinformasikan bahwa penempatan dana pada bank syariah akan mendapatkan keuntungan lebih berkah, di samping aktifitas perbankan yang dilakukan pada bank-bank syariah tentu dapat bernilai ibadah. Praktek pengelolaan perbankan perlu secara riil menunjukkan nilai syariah, sehingga pilihan masyarakat lebih besar untuk ke bank-bank syariah.

4. Benchmarking instrumen operasional dan produk. Sebagai industri yang baru muncul, industri perbankan syariah masih memiliki cakupan operasi dan produk 
yang sangat terbatas dalam rangka memfasilitasi kebutuhan transaksi nasabah, sehingga dalam beberapa hal tertentu pengembangan instrumen operasional dan produk masih mengacu pada perbankan konvensional.

5. Lingkungan makro-ekonomi. Sifat operasional perbankan syariah yang secara langsung bersentuhan dengan sektor rill sangat terkait dengan perkembangan lingkungan makro-ekonomi, sehingga upaya untuk mewujudkan dan menjaga kondisi makro-ekonomi yang stabil merupakan tantangan yang perlu diperhitungkan dalam pengembangan perbankan syariah dan lembaga keuangan syariah.

6. Peraturan perbankan yang berlaku belum sepenuhnya mengakomodasi operasional bank syariah. ${ }^{31}$

Harus diakui bahwa perkembangan perbankan syariah hingga saat ini memang masih menunjukkan pertumbuhan yang belum maksimal, khususnya bila dibandingkan secara komprehensif dengan pertumbuhan bank konvensional. Hal itu ditunjukkan dengan populasi bank syariah yang masih kecil. Tantangan dan permasalahan yang dihadapi dalam pengembangan perbankan syariah terutama berkaitan dengan pelaksanaan suatu sistem perbankan yang baru. Suatu sistem yang mempunyai dasar perbedaan dengan sistem yang lama digunakan di Indonesia.

Dalam rangka menghadapi tantangan-tantangan penyelenggaraan ekonomi syariah di atas, pemerintah Indonesia telah mengambil langkah untuk membangun kembali sistem perbankan yang sehat. Pemerintah dalam hal ini berupaya melakukan pengembangan sistem perbankan syariah. Tujuan pengembangan syariah adalah untuk:

1. Keperluan jasa perbankan bagi masyarakat yang tidak dapat menerima konsep bunga bank.

\footnotetext{
${ }^{31}$ Amran Suadi dan Mardi Candra, Politik Hukum: Perspektif Hukum Perdata dan Pidana Islam serta Ekonomi Syariah, h. 431 dan 461-463.
} 
2. Peluang pembiayaan bagi pengembangan usaha berdasarkan prinsip kemitraan.

3. Keperluan akan produk dan jasa perbankan unggulan.

Berdasarkan tujuan tersebut, maka strategi pengembangan bank syariah diarahkan untuk meningkatkan kompetensi usaha yang sejajar dengan sistem perbankan konvensional yang dilakukan secara komprehensif dengan mengacu kepada analisis kekuatan dan kelemahan perbankan syariah di Indonesia. Fokus utama strategi pengembangan sistem perbankan syariah meliputi hal-hal sebagai berikut:

1. Penyempurnaan ketentuan. Upaya yang dilakukan adalah penyesuaian perangkat bank sentral, Undang-Undang Perbankan, dan penyususunan perangkat ketentuan pendukung kegiatan operasional bank syariah.

2. Pengembangan jaringan bank syariah. Hal itu ditujukan untuk menyediakan akses yang lebih luas kepada masyarakat dalam mendapatkan pelayanan jasa bank syariah. Pengembangan jaringan ini dilakukan dengan cara: pertama, peningkatan kualitas bank umum syariah dan bank perkreditan rakyat syariah (BPRS) yang telah beroperasi. Kedua, perubahan kegiatan usaha bank konvensional yang memiliki kondisi usaha yang baik dan berminat untuk melakukan kegiatan usaha bank berdasarkan prinsip syariah. Ketiga, pembukaan pejabat bank syariah bagi bank konvensional yang memiliki kondisi usaha bank berdasarkan prinsip syariah.

3. Pengembangan keamanan mata uang. Hal ini bertujuan untuk membantu pengembangan pasar uang antar bank syariah.

4. Pelaksanaan sosialisasi perbankan syariah. Usaha ini dilakukan untuk memberikan informasi yang lengkap dan benar mengenai kegiatan usaha perbankan syariah kepada masyarakat. ${ }^{32}$

\footnotetext{
${ }^{32}$ Amran Suadi dan Mardi Candra, Politik Hukum: Perspektif Hukum Perdata dan Pidana Islam serta Ekonomi Syariah, h. 431.
} 


\section{KESIMPULAN}

Setelah menguraikan beberapa aspek yang berkaitan dengan tantangan penyelenggaraan ekonomi syariah khususnya di Indonesia, maka kesimpulan yang dapat dipetik adalah:

1. Filosofi ekonomi syariah mencakup beberapa nilai, yaitu nilai keTuhanan, nilai kepemilikan (al-Milkiyah), nilai keseimbangan (al-Muwāzanah), nilai dasar persaudaraan dan kebersamaan (al-Ukhuwwah wa al-Isytirākiyyah wa al-Jamā'ah), nilai dasar kebebasan (al-Istiqlāliyyah), nilai keadilan (al-'Adālah).

2. Alas sejarah penyelenggaraan ekonomi syariah diinspirasi dari kajian-kajian ilmiah tentang ekonomi dan keuangan Islam di Timur Tengah serta negara-negara muslim lainnya sejak pertengahan dekade 1970-an yang berbuah pendirian Islamic Development Bank. Di Indonesia, penyelenggaraan ekonomi syariah identik dengan pendirian bank-bank syariah, setelah sebelumnya para pakar/cendekiawan muslim baik yang ada di organisasi keagamaan maupun kalangan perbankan dan perorangan, telah melakukan pengkajian tentang bunga bank dan riba. Kemudian gagasan pendirian bank syariah tersebut juga dibicarakan pada seminar nasional tentang "Hubungan Indonesia-Timur Tegah" (1974) dan seminar internasional yang diselenggarakan oleh Lembaga Studi Ilmu-ilmu Kemasyarakatan (LSIK) dan Yayasan Bhinneka Tunggal Ika (1976). Walhasil, titik awal pendirian perbankan yang mempergunakan prinsip syariah ditandai dengan berdirinya PT. Bank Muamalat Indonesia TBK pada tahun 1991.

3. Tantangan penyelenggaraan ekonomi syariah di Indonesia dapat dilihat dari sisi belum maksimalnya sosialisasi ekonomi syariah, lemahnya jaringan atau sinergi yang kuat antara sesama lembaga keuangan syariah dengan lembaga-lembaga sosial yang bergerak di bidang ekonomi umat, di samping faktor kelembagaan, sumber daya manusia, pemahaman masyarakat, benchmarking instrumen operasional dan produk, lingkungan makro-ekonomi dan regulasi perbankan, juga menjadi hambatan yang perlu dipecahkan. 


\section{DAFTAR PUSTAKA}

Akbar, A., Dahri, M., \& Arsyam, M. (2021). Konsep Dasar Ekonomi Dan Transaksi Dalam Muamalah Islam.

Janna, N. M., \& Arsyam, M. (2021). Makanan Dan Minuman Dalam Islam.

Usman, H. A., Arsyam, M., \& Yusuf, M. (2021). ETIKA PERDAGANGAN DALAM ISLAM.

Sapada, A. O. (2020). Mendidik Anak Menjadi Anak Sholeh.

Arsyam, M., \& Alwi, A. M. (2020). MANAJEMEN HIDUP DALAM PERSPEKTIF ALQUR'AN.

Zakirah, Z., Jumliadi, J., Arsyam, M., Herianto, H., Rusli, M., \& Alwi, A. M. Implementation of The Islamic Local Regulations in Bulukumba Regency.

Nursalam, N., Basri, A., \& Akbar, A. Implementasi Nikah Dalam Al-Qur'an (Studi Pendekatan Tafsir Maudu'i).

Akbar, A., Basri, A., \& Jamaluddin, H. (2021). Konsep Integrasi Ilmu Agama Dan Ilmu Umum.

Abdul Hakim, Atang. Fiqih Perbankan Syariah; Transformasi Fiqih Muamalah ke Dalam Peraturan Perundang-Undangan. Bandung: Refika Aditama, 2011.

Aziz, Abdul dan Mariyah Ulfah. Kapita Selekta Ekonomi Islam Kontemporer. Bandung: Alfabeta, 2010.

A. Prawiraatmajdja, Karnaen dan Henri Tanjung. Bank Syariah; Teori, Praktik, dan Peranannya. Jakarta: Celestial Publishing, 2007.

Anshari, Endang Saefuddin. Kuliah al-Islam; Pendidikan Agama Islam di Perguruan Tinggi. Jakarta: Raja Grafindo Persada, 1992.

Departemen Agama RI. Al-Qur'an dan Terjemahnya. Jakarta: Yayasan Penterjemah al-Qur'an, 1983.

https://journal.uinjkt.ac.id/index.php/salam/artcle/downloadSuppFile/1521/97.x (Diakses 20 Juni 2018).

Isretno, Evita. Pembiayaan Mudharabah dalam Sistem Perbankan Syariah (Jakarta: Cintya Press, 2011.

Jayadi, Abdullah. Beberapa Aspek Penting tentang Perbankan Syariah. Cet. I; Yogyakarta: Mitra Pustaka, 2011.

Nafis, M. Cholil. Teori Hukum Ekonomi Syariah. Jakarta: UI-Press, 2011.

Qardhawi, Yusuf. Norma dan Etika Ekonomi Islam. Jakarta: Gema Insani Press, 1997.

Peran dan Nilai Moral dalam Perekonomian. Jakarta: Rabbani Press, 1995.

Rakhmat, Jalaluddin. Islam alternatif: Ceramah-Ceramah di Kampus. Bandung: Mizan, 2004.

Suadi, Amran dan Mardi Candra, Politik Hukum: Perspektif Hukum Perdata dan Pidana Islam serta Ekonomi Syariah. Jakarta: Kencana, 2016.

Sumitro, Warkum. Asas-Asas Perbankan Islam dan Lembaga-Lembaga Terkait; Bamui, Takaful dan Pasar Modal Syariah di Indonesia. Jakarta: Raja Grafindo Persada, 2004.

Yusuf, Ali Anwar. Islam dan Sains Modern: Sentuhan Islam terhadap Berbagai Disiplin Ilmu. Bandung: Pustaka Setia, 2006. 